INTERMATIONAL JOURNAL
OF
PHARMACEUTICAL SCIENCES
RESEARCH

Received on 09 January, 2013; received in revised form, 09 April, 2013; accepted, 25 April, 2013

\title{
DEVELOPMENT AND VALIDATION OF UV SPECTROPHOTOMETRIC METHOD FOR ESTIMATION OF GLIPIZIDE IN BULK AND PHARMACEUTICAL DOSAGE FORMS
}

\author{
Vaishali V. Karkhanis*, Anandkumari D. Captain and Priti H. Patel
}

A.R. College of Pharmacy and G.H. Patel Institute of Pharmacy Vallabh Vidhyanagar, Dist: Anand-388120, Gujarat, India

Keywords:

UV-Vis Spectrophotometer, Glipizide (GLP), Recovery, $\Lambda_{\max }$

\section{Correspondence to Author:}

Vaishali V. Karkhanis

Assistant Professor, A.R. College of Pharmacy and G.H. Patel Institute of Pharmacy Vallabh Vidhyanagar, Dist: Anand-388120, Gujarat, India

E-mail: vesli@rediffmail.com

\begin{abstract}
A selective, simple, accurate and reproducible spectrophotometric method has been developed for the estimation of Glipizide in bulk and pharmaceutical formulation. Glipizide is a second generation sulfonylurea which lowers blood glucose in patients with diabetes mellitus type II. The drug obeyed the Beer's law and showed good correlation. It showed absorption maxima at $276 \mathrm{~nm}$ in $0.1 \mathrm{~N}$ $\mathrm{NaOH}$. The developed method was validated with respect to linearity, accuracy and precision in accordance with the requirements of ICH guidelines. The linearity was observed between $10-30 \mu \mathrm{g} / \mathrm{ml}$ having line equation $\mathrm{Y}=0.0283 \mathrm{X}-0.0248$ with correlation coefficient of 0.999 . The limit of quantification and limit of detection were found to be 1.643 and $0.542 \mathrm{ug} / \mathrm{ml}$ respectively. Moreover, the proposed analytical method is thus potentially useful for a routine laboratory because of its simplicity, rapidity, precision and accuracy.
\end{abstract}

INTRODUCTION: Glipizide,N-[2(4\{[(Cyclohexyl carbamoyl)amino]sulfonyl \}phenyl)ethyl]-5-methyl pyrazine-2-carboxamide ${ }^{1}$, is an oral hypoglycaemic agent. Glipizide mainly acts by stimulation of insulin release from the $\beta$ cells of the pancreas by blocking the ATP-sensitive $\mathrm{K}^{+}$Channels, resulting in depolarization and $\mathrm{Ca}^{2+}$ reduction in hepatic glucose production $^{2,3}$. Several methods have been published for the determination of GLP, either in pharmaceutical preparations and biological fluids. These methods include spectrophotometry ${ }^{4}$, HPTLC 5 and HPLC ${ }^{6,7,8-13}$. There is a need to develop and validate a new simple, rapid, reliable and precise UV spectrophotometric method for analysis of GLP in bulk and tablet formulation. Suitable statistical tests were performed on validation data ${ }^{14,15}$.

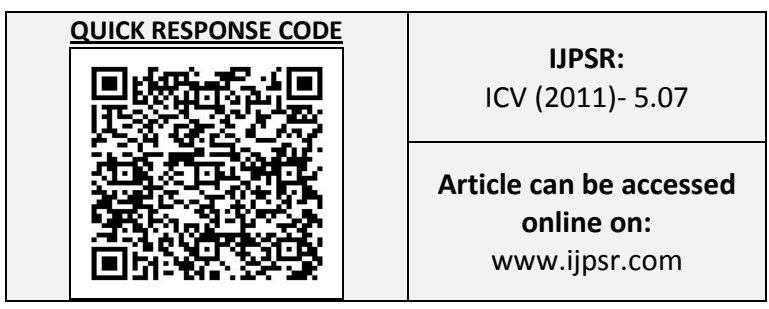

\section{MATERIALS AND METHODS:}

\section{Instrument Used:}

A- Model: UV-Vis spectrophotometer 1700, Make: Shimadzu, Kyoto, Japan, Scan speed: 40nm/min

B. Bath Sonicator

Reagents and Solutions: All the reagents used in this assay were of analytical grade. Tablets of GLP were purchased.

\section{EXPERIMENTAL:}

Determination of $\boldsymbol{\Lambda}_{\max }$ : Weighed amount of GLP was dissolved in $0.1 \mathrm{~N} \mathrm{NaOH}$ to obtain a $100 \mu \mathrm{g} / \mathrm{ml}$ solution. This solution was subjected to scanning between 200-400 $\mathrm{nm}$ and absorption maximum was determined. The effect of dilution on absorption maxima was studied by diluting the above stock solution to $20 \mu \mathrm{g} / \mathrm{ml}$ and scanned from $200-400 \mathrm{~nm}$. 
Preparation of Standard Stock Solution: Standard drug solution of GLP was prepared by dissolving 10 mg GLP in $100 \mathrm{ml} 0.1 \mathrm{~N} \mathrm{NaOH}$ to obtain stock solution of $100 \mu \mathrm{g} / \mathrm{ml}$ concentration.

Preparation of Calibration Curve: Calibration curve was prepared in $0.1 \mathrm{~N} \mathrm{NaOH}$ at $K_{\max } 276 \mathrm{~nm}$ using UV-Vis spectrophotometer Model 1700. For this stock solution of $100 \mu \mathrm{g} / \mathrm{ml}$ was prepared. Serial dilution of $10,15,20,25,30 \mu \mathrm{g} / \mathrm{ml}$ were prepared and absorbance was taken at $\Lambda_{\max } 276 \mathrm{~nm}$. Averages of such 6 sets of values were taken for calibration curve, and solution were scanned in the range of 200$400 \mathrm{~nm}$ against blank.

Assay: Ten Tablets each containing of $5 \mathrm{mg}$ of GLP was weighed and powdered. Powder equivalent to $100 \mathrm{mg}$ of GLP was transferred into $100 \mathrm{ml}$ volumetric flask dissolved in $0.1 \mathrm{~N} \mathrm{NaOH}$. The solution was then filtered through Whatmann filter paper No 40 (0.45 micron).Aliquots of the sample were removed and diluted to $10 \mathrm{ml}$ of $0.1 \mathrm{~N} \mathrm{NaOH}$ to obtain strengths of $20 \mu \mathrm{g} / \mathrm{ml}$ determined at the respective absorbance of $276 \mathrm{~nm}$ against $0.1 \mathrm{~N} \mathrm{NaOH}$ as a blank.

\section{Limit of Detection (LOD) and Limit of} Quantification (LOQ): The LOD and LOQ of GLP were determined by using standard deviation of the response and slope approach as defined in International Conference on Harmonization (ICH) guidelines ${ }^{7}$. The LOD and LOQ were found to be as in Table 1. Limit of detection (LOD) and limit of quantification (LOQ) were calculated by Eq. (1) $\mathrm{LOD}=3.3 \delta / \mathrm{s}$ and (2) $\mathrm{LOQ}=10 \delta / \mathrm{s}$ respectively, where $\delta$ is the standard deviation of blank and $s$ is slope.

Recovery studies: Recovery studies were performed to judge the accuracy of the method. Recovery studies were carried out by adding a known quantity of pure drug to the pre-analyzed formulation and the proposed method was followed. From the amount of drug found, percentage recovery was calculated. Recovery study was carried out by addition of standard drug to the sample at 3 different concentration levels.

RESULTS AND DISCUSSION: The UV scan of standard solution between $200-400 \mathrm{~nm}$ showed the absorption maxima at $276 \mathrm{~nm}$. The overlay spectra of different concentration range of standard GLP was recorded (Figure 1). The Beer's law was verified from the calibration curve by plotting a graph of concentration vs. absorbance (Figure 2). The linearity range was observed between $10-30 \mu \mathrm{g} / \mathrm{ml}$. The plot clearly showed a straight line passing through origin with equation $\mathrm{Y}=0.0283 \mathrm{X}-0.0248$ with correlation coefficient of 0.999 . The coefficient of correlation was highly significant. The optical characteristics and other validation parameters are thus summarised in Table 1. The assay method was validated by low values of standard deviation and standard error, indicating accuracy and precision (Table 2) of the methods. Excellent recovery studies further prove the accuracy of the method (Table 3). The assay result was repeated for three times which was found to be $99.16-101.66 \%$ of labelled claim (Table 4).

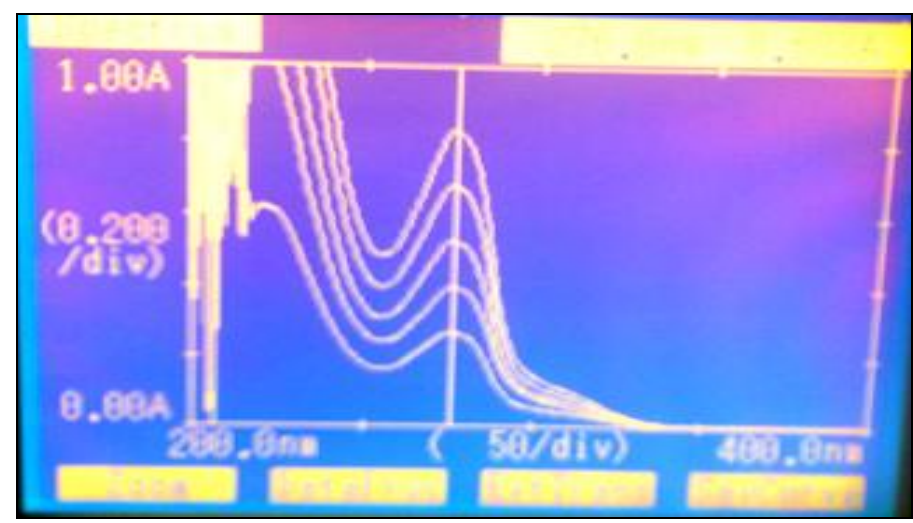

FIGURE 1: OVERLAIN SPECTRUM OF GLIPIZIDE

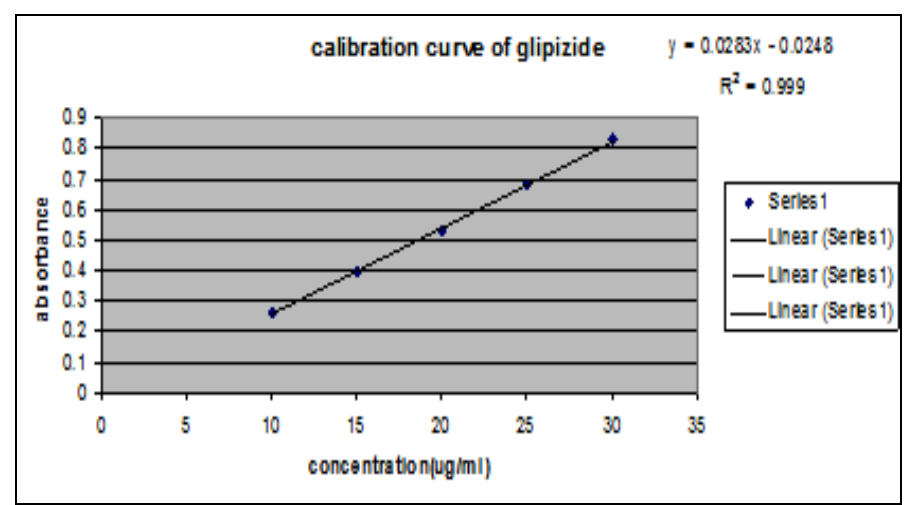

FIGURE 2: CALIBRATION CURVE OF GLIPIZIDE

TABLE 1: OPTICAL PARAMETERS FOR GLP

\begin{tabular}{ccc}
\hline Sr. no. & Parameters & values \\
\hline 1 & max $(\mathrm{nm})$ & 276 \\
2 & linearity range & $10-30 \mu \mathrm{g} / \mathrm{ml}$ \\
3 & regression equation & $\mathrm{Y}=0.0283 \mathrm{X}-0.0248$ \\
4 & correlation coefficient & 0.999 \\
5 & slope & 0.0283 \\
6 & intercept & 0.0248 \\
7 & Limit of detection $(\mu \mathrm{g} / \mathrm{ml})$ & 0.5423 \\
8 & Limit of quantification $(\mu \mathrm{g} / \mathrm{ml})$ & 1.6433 \\
\hline
\end{tabular}


TABLE 2: PRECISION DATA FOR GLP

\begin{tabular}{cccccc}
\hline Sr. no. & Conc. ug/ml & intraday & cv & Interday & cv \\
\hline 1 & 15 & $0.3866 \pm 0.00294$ & 0.7613 & $0.3818 \pm 0.0042$ & 1.103 \\
2 & 20 & $0.5493 \pm 0.0087$ & 1.589 & $0.5468 \pm 0.0076$ & 1.399 \\
3 & 25 & $0.6853 \pm 0.0025$ & 0.3652 & $0.686 \pm 0.0039$ & 0.573 \\
\hline
\end{tabular}

TABLE 3: RECOVERY STUDY DATA FOR GLP

\begin{tabular}{ccccc}
\hline Sr. no. & Amount of sample (ug/ml) & Added drug (ug/ml) & Drug recovered $(\mathbf{u g} / \mathbf{m l}) \mathbf{\pm} \mathbf{s d}$ & \% recovery \\
\hline 1 & 20 & 0 & $19.6933 \pm 0.2571$ & 98.4666 \\
2 & 20 & 10 & $29.6866 \pm 0.1501$ & 98.9555 \\
3 & 20 & 20 & $39.2866 \pm 0.2715$ & 98.2166 \\
4 & 20 & 30 & $49.1833 \pm 0.1844$ & 98.3666
\end{tabular}

TABLE 4: ASSAY RESULTS FOR GLP

\begin{tabular}{cccc}
\hline Sr. no. & Actual conc. $(\boldsymbol{\mu g} / \mathbf{m l})$ & Amount obtained $(\boldsymbol{\mu g} / \mathbf{m l})$ & $\boldsymbol{\%}$ drug \\
\hline 1 & 20 & 19.89 & 99.45 \\
2 & 20 & 19.86 & 101.66 \\
3 & 20 & 19.99 & 99.16 \\
\hline
\end{tabular}

CONCLUSION: It can be concluded that the proposed method is simple, rapid, accurate, precise, economic and reproducible for UV spectrophotometric estimation of GLP from pharmaceutical formulation. This method can be successfully applied for routine estimation of GLP in bulk and pharmaceutical dosage form.

ACKNOWLEDGEMENTS: The authors wish to thank Prof. A.K. Saluja (Principal) A.R. College of Pharmacy and G.H. Patel Institute of Pharmacy for providing laboratory, store and library facility and last but not the least we wish to thank to all our friends and colleagues for their valuable support.

\section{REFERENCES:}

1. http://www.drugbank.ca/drugs/DB01067.

2. Wilson and Gisvolds, Text book of organic medicinal and pharmaceutical chemistry, eleventh edition, edited by John H. Block, John M. Beale, Jr. Lippincott Williams and Wilkins, Wolters Kluwer, London UK: 2004; 670.

3. Goodman and Gilman's, The pharmacological basis of therapeutics, 11 th edition, edited by Laurence L. Brunton, John S. Lazo, Keith L. Parkar, McGraw-Hill, Medical publishing division,2006:1635-1638.

4. Dhabale, Seervi C.R: Simple, accurate, precise, reproducible and economical procedures for simultaneous estimation of Glipizide and Metformin hydrochloride in tablet dosage form. International Journal of ChemTech Research, 2009; Vol.2: 813-817.

5. Darshana K. Modi and Bhavesh H. Patel, Simultaneous determination of metformin hydrochloride and glipizide in tablet formulation by HPTLC, J. of Liquid Chromatography and Related Technologies, 2012; 35(1):28-39.
6. P. Venkatesh, T. Harisudhan, Hira Choudhury, Ramesh Mullangi, Nuggehally R. Srinivas: Simultaneous estimation of six anti-diabetic drugs-glibenclamide, gliclazide, glipizide, pioglitazone, repaglinide and rosiglitazone: Development of a novel HPLC method for use in the analysis of pharmaceutical formulations and its application to human plasma assay. Biomedical Chromatography, 20: 1043-1048.

7. $\mathrm{Yu} \mathrm{H}$ Nola, Ho NM Emmie, Tang P. W Francis, Wan S.M. Terence:To develop the simple, stability-indicating reversed-phase high-performance liquid chromatographic (RP-HPLC) method for determination of Glipizide in guinea pig plasma, Journal of Chromatography A,2008; Vol.1, Issues 1-2: 426-434.

8. S Dhawan, A K Singla, High Performance liquid chromatographic analysis of glipizide: application to in vitro and in vivo studies. J Chromatogr Sci. 2003; 41 (6):295-300.

9. Swaroop R. Lahoti, Prashant K. Puranik, Ashish A. Heda, Rajesh B. Navale: Development and Validation of RP-HPLC Method for Analysis of Glipizide in Guinea Pig Plasma and its Application to Pharmacokinetic Study, International Journal of Pharm Tech Research, $2010 ; 2(3)$ : 1649-1654.

10. Shaikh Rahila, Karigar Asif: Reverse phase high performance liquid chromatographic method for the analysis of glipizide in pharmaceutical dosage forms, International Journal of Research in Ayurveda \& Pharmacy, 2010; 1(2): 455-458.

11. S. AbuRuza, b, J. Millershipb and J. McElnayb: The development and validation of liquid chromatography method for the simultaneous determination of metformin and glipizide, gliclazide, glibenclamide or glimepiride in plasma, $\mathrm{J}$ of Chromatography $\mathrm{B}$, 2005; 817 (2): 277-286.

12. B. Udaykumar Rao and Anna Pratima Nikalje: Determination of Glipizide, Glibenclamide and Glimeperide in a Tablet Dosage Form in the Presence of Metformin Hydrochloride by Ion Pair -Reversed Phase Liquid Chromatographic Technique, J Anal Bioanal Techniques, 2010; 1(2):105.

13. Anna Gumieniczek and Anna Berecka, Quantitative analysis of gliclazide and glipizide in Tablets by a new validated and stabilityindicating RPTLC method, J of Planar Chromatography, 2010; 23(2): 129-133.

14. International conference on Harmonization, Guidance for Industry In; Q2A Text on Validation of Analytical Methods, Switzerland; IFPMA 1994;1-4.

15. International conference on Harmonization, Guidance for Industry In; Q2B Validation of Analytical Procedures, Methodology, Switzerland; IFPMA 1996; 1-8.

How to cite this article:

Karkhanis VV, Captain AD and Patel PH: Development and Validation of UV Spectrophotometric method for estimation of Glipizide in Bulk and Pharmaceutical Dosage Forms. Int J Pharm Sci Res 2013; 4(5); 1865-1867. 